\title{
Mandatory Audit Firm Rotation for Listed Companies: The Effects in the Netherlands
}

\author{
Bas de Jong ${ }^{1}$ - Steven Hijink ${ }^{1}$ - Lars in 't Veld ${ }^{1}$
}

Published online: 3 August 2020

(c) The Author(s) 2020

\begin{abstract}
The Audit Regulation was adopted in 2014 to address many of the perceived failings in the market for statutory audits. It introduced mandatory audit firm rotation for public-interest entities, including listed companies, as of 17 June 2020/2023. Mandatory audit firm rotation was also considered by the Dutch legislator in 2012. Therefore, many Dutch listed companies had already switched audit firm in anticipation of the national requirement. In this article, we investigate the effects of mandatory audit firm rotation in the Netherlands by examining the financial reports of Dutch listed firms over the financial years 2012-2016 and by conducting a survey among stakeholders. We conclude that there is broad support for mandatory audit firm rotation in the Netherlands. Although mandatory audit firm rotation was seen as controversial at the time of adoption, it is now considered desirable by various stakeholders, including auditors themselves. However, mandatory audit firm rotation appears to have had some adverse effects. Most notably, our study shows a higher probability of errors in first year audits. The discount in audit fees provided by audit firms to lucrative larger public-interest entities for first year audits- the trophy client effect-may exacerbate the negative effect on audit quality. The Audit Regulation's goals to improve the market for statutory audits have not been met so far.
\end{abstract}

Keywords Audit Regulation · Audit firm rotation · Audit quality · The Netherlands

Bas de Jong

b.dejong@jur.ru.nl

Lars in 't Veld

1.intveld@jur.ru.nl

Steven Hijink

j.hijink@jur.ru.nl

1 Radboud Business Law Institute, Radboud University Nijmegen, Nijmegen, The Netherlands 


\section{Introduction}

During the last decade, the quality of statutory audits of listed companies has regularly been questioned. This occurs in particular if a company faces financial distress or fraud, and audit reports of previous financial years did not provide any clue as to the mounting problems. Recent examples in the UK are the collapse of the construction group Carillon and the pension scandal at British Home Stores (BHS). Other cases include a corruption scandal at the oil company Petrobras in Brazil, and accounting irregularities at the retail company Steinhoff in the Netherlands/South Africa.

After the financial crisis, the European legislator tried to address many of the perceived failings in the market for statutory audits by adopting the Audit Regulation of 2014. ${ }^{1}$ The Audit Regulation became effective from 17 June 2016.

One of the measures in the Audit Regulation is mandatory audit firm rotation for public-interest entities (hereafter PIEs), which include listed companies. ${ }^{2}$ This means that listed companies should rotate from audit firm after a certain period of time. In other words, there is a maximum duration of the audit engagement. The assumption is that long-lasting audit engagements result in audit firms being less independent and less critical, ultimately leading to lower quality audits. Moreover, mandatory rotation could improve competition in the market for statutory audits. ${ }^{3}$ The so-called Big Four audit firms-Deloitte, EY, KPMG and PwC-dominate this market, which is seen as undesirable, as a sufficient choice of audit firms is assumed to be required in order to ensure a smooth functioning of capital markets. ${ }^{4}$

Introducing mandatory audit firm rotation was also considered by the Dutch legislator in 2012, independently from the European legislator. For quite some time, it was expected that the said Dutch national legislation would apply as of 1 January 2014, which date was later postponed to 1 January 2016. Ultimately, the Dutch legislator conformed to the Audit Regulation and dropped the national requirement in September 2015. The Audit Regulation does not require listed companies to rotate from audit firm as of 2014 or 2016, but grants them time until 17 June 2020/2023. ${ }^{5}$ However, many Dutch listed companies already rotated from audit firm in anticipation of the national requirement which was expected to apply much earlier. Thus, in

\footnotetext{
1 Council Regulation (EU) 537/2014 on specific requirements regarding statutory audit of public-interest entities [2014] OJ 158/77 (hereafter Audit Regulation).

2 Art. 17 Audit Regulation. For the definition of PIEs, see Art. 2 Council Directive 2006/43/EC [2006] OJ 157/87 (hereafter Audit Directive), as amended by Council Directive 2014/56/EU [2014] OJ L 158/196. In this article we focus on 'entities governed by the law of a Member State whose transferable securities are admitted to trading on a regulated market of any Member State within the meaning of point 14 of Art. 4(1) of Directive 2004/39/EC', as mentioned in this Art. 2.

3 See recital 21 of the Audit Regulation.

4 See recital 30 of the Audit Regulation and SEC(2011) 1384 final, pp 17 et seq., 8, 29 (hereafter the European Commission Impact Assessment).

5 Art. 41 Audit Regulation. As from 17 June 2020, audit engagements cannot be entered into or renewed if the auditor or audit firm has been providing audit services for 20 and more consecutive years at the date of entry into force of the Regulation. As from 17 June 2023, this applies if audit services have been provided for 11 and more but less than 20 consecutive years at the date of entry into force.
} 
the Netherlands we experienced about 5 years of (anticipated) mandatory audit firm rotations.

In this article, we investigate the effects of (anticipated) mandatory audit firm rotation in the Netherlands. By doing so, our aim is to answer the question to what extent the goals in the Audit Regulation have been achieved. Before the adoption of the Audit Regulation, mandatory audit firm rotation within the EU only existed in Italy. The Italian experience was taken into account when designing the Audit Regulation.

First, we briefly analyze the Audit Regulation. Its background, goals and measures relating to mandatory audit firm rotation will be discussed (Sect. 2). Next, we will present the experiences with mandatory audit firm rotation in the Netherlands. We conducted empirical research by studying annual financial reports of listed companies over the period 2012-2016, and by conducting a survey among stakeholders (Sect. 3). We will discuss the relevance of the outcomes for the EU and its member states (Sect. 4). The article finishes with our conclusion (Sect. 5).

\section{Mandatory Audit Firm Rotation: The Audit Regulation and Dutch Law}

\subsection{The Audit Regulation}

\subsubsection{Mandatory Audit Firm Rotation: Background, Advantages and Aims}

The Audit Regulation was preceded by a thorough European Commission Impact Assessment, which discusses the pros and cons of mandatory audit firm rotation. ${ }^{6}$ According to the European Commission, one of the threats to the independence of auditors is the 'familiarity' threat. ${ }^{7}$ The auditor may be too sympathetic to the interests of the company in the case of a close and long relationship. Also, the audit work tends to concentrate on routine and a repetition of the previous year audit, so that the auditor no longer has a fresh view to suggest improvements. Academic studies show that long engagement terms are more likely to increase 'materiality' thresholds, and a higher probability of favourable auditors' reports. ${ }^{8}$ Some believe that regular mandatory rotation will also promote scrutiny of the auditor's work by the next incoming auditor, which may give the auditor incentives to do a better job. ${ }^{9}$

In many countries, companies have been audited by the same audit firm for decades. This might be an inherent risk of the current system in which (the general

\footnotetext{
6 The European Commission Impact Assessment, pp 26, 37-45, 171-177.

7 The other threats are the provision of non-audit services and the fact that the audited company selects and pays the auditor. If audit firms have an interest in securing additional revenue from the provision of other non-audit services, this could jeopardize professional skepticism when conducting the statutory audit. When the auditor is de facto selected and paid by the audited firm's management, this undermines the auditor's independence. We do not further discuss these issues.

${ }^{8}$ E.g. Arel et al. (2005), cited by the European Commission Impact Assessment.

${ }^{9}$ Hoyle (1978), cited by the European Commission Impact Assessment.
} 
meeting of) the audited company, based on a proposal of the audited company's supervisory board and a recommendation made by the audit committee, ${ }^{10}$ selects the audit firm and the auditor. Moreover, in the current system there is (the perception of) an undesirable situation of the audited company paying the auditor. One of the specific objectives of the Audit Regulation is to mitigate the risks of this (perceived) dependency relation in the system (the so-called familiarity threat) by reinforcing the independence and professional scepticism of statutory auditors and audit firms when conducting statutory audits to PIEs. Mandatory audit firm rotation is believed to be one of the measures, aiming to reduce and mitigate the risk of a lack of independency and professional scepticism.

Barriers to entry into the statutory audit market for PIEs are also considered a problem, according to the European Commission. The choice of a PIE for an audit firm to conduct a statutory audit is effectively limited to the Big Four audit firms, or even more limited if one of the Big Four audit firms already provides other services to the said PIE. In 2011, the market share of the Big Four audit firms exceeded $85 \%$ in the vast majority of member states. ${ }^{11}$ As a result, large audit firms may be too big to fail, and the market structure may induce a moral hazard whereby public authorities could be required to save an audit firm or display regulatory forbearance. Consequently, a specific objective of the Audit Regulation is to improve the conditions of the market for statutory audits of PIEs by facilitating the rotation of audit firms, facilitating an objective choice of audit firms and increasing the choice of audit firms. $^{12}$

Regarding the goals of mandatory audit firm rotation, the Audit Regulation's recital 21 states:

In order to address the familiarity threat and therefore reinforce the independence of statutory auditors and audit firms, it is important to establish a maximum duration of the audit engagement of a statutory auditor or an audit firm in a particular audited entity. In addition, as a means of strengthening the independence of the statutory auditor or the audit firm, reinforcing professional scepticism, and increasing audit quality, this Regulation provides for the following alternatives for an extension of the maximum duration: regular and open mandatory retendering or the appointment of more than one statutory auditor or audit firm by public-interest entities. Also, the involvement of smaller audit firms in these measures would facilitate the development of the capacity of such firms, thus broadening the choice of statutory auditors and audit firms for public-interest entities. It is also important to provide for an appropriate period within which such statutory auditor or audit firm may not carry out the statutory audit of the same entity. In order to ensure a smooth transition, the former statutory auditor should transfer a hand-over file with relevant information to the incoming statutory auditor.

\footnotetext{
10 Art. 37 Audit Directive and Art. 16 Audit Regulation.

11 The European Commission Impact Assessment, pp 8-9.

12 Ibid., p 26. See also Köhler, Quick and Willekens (2016).
} 
Hence, the following (related) goals of the Audit Regulation can be extracted, which goals have been part of our empirical analysis in the Netherlands (Sect. 3):

- reducing the familiarity threat;

- reinforcing professional skepticism;

- reinforcing the independence of audit firms;

- increasing audit quality; and

- broadening the choice of statutory auditors and audit firms for PIEs (through improving market structure).

The Audit Regulation introduced a combination of measures to achieve these goals:

- a maximum duration of the audit engagement (10 years is the default);

- an extension of this maximum by a qualified form of retendering or by the appointment of a second audit firm;

- a cooling-off period (4 years is the default) within which the audit firm cannot carry out an audit.

The requirement of key partner rotation within an audit firm — which was already mandatory due to the Audit Directive - is also upheld in the Audit Regulation. We will discuss this package of measures in detail in Sect. 2.1.3.

\subsubsection{Mandatory Audit Firm Rotation: Disadvantages}

It is admitted in the European Commission Impact Assessment that mandatory audit firm rotation is controversial and has attracted opposition from many stakeholders, including auditors and the European Parliament. ${ }^{13}$ Some opponents believe that partner rotation (instead of firm rotation) is sufficient to deal with independence concerns. Moreover, it is argued that the experience in Italy - the only member state that had a requirement of mandatory audit firm rotation in place before the adoption of the Audit Regulation - has not been unanimously positive and the Italian market is as concentrated as the audit market in other member states. ${ }^{14}$

The European Commission recognized that mandatory audit firm rotation may have certain disadvantages and leads to additional costs for both PIEs and audit firms. ${ }^{15}$ There could be additional initial costs in the first year of a statutory audit mandate. Audit firms will need to invest to gather sufficient knowledge with regard to their new audit client. It also takes time to become familiar with the special procedures, systems and recent history of the entity. ${ }^{16}$ As audit firms constantly need to

\footnotetext{
13 The European Commission Impact Assessment, pp 172-175.

14 SDA Università Bocconi (2002); Cameran et al. (2005), pp 37-38, 42.

15 The European Commission Impact Assessment, pp 174-175.

16 See a.o. Lee et al. (2009); Dao and Pham (2014).
} 
recoup start-up costs and efforts, this may lead to a less critical attitude. ${ }^{17}$ PIEs will also incur additional costs to assist the new audit firm. According to the European Commission, the frequency of audit firm rotation should not be too high to take into account these additional costs during the first or second year audit. Moreover, the European Commission argues that the initial time period for the engagement should not be for less than 5 years and a possibility to renew the contract should be given once. $^{18}$

Another concern raised in the literature is that audit firm rotation leads to a loss of knowledge of the audited firm and the industry. The previous auditor had firmspecific knowledge, which is lost due to rotation. There is some empirical evidence that there is a higher risk of audit failure due to this lack of firm-specific knowledge. ${ }^{19}$ According to the European Commission, it is therefore important that the incoming auditor has access to a hand-over file prepared by the outgoing auditor. A joint audit is also seen as a solution to minimize this risk. Regarding industry knowledge, the European Commission observes that this knowledge can also be obtained by working with external specialists. ${ }^{20}$

Regarding market structure, a study by Bocconi ${ }^{21}$ found that mandatory audit firm rotation in Italy did not have much impact on the level of competition, nor did it give medium-sized audit firms the opportunity to compete against large audit firms for contracts with PIEs. A related concern is that mandatory audit firm rotation may lead to a lack of choice when appointing a new auditor. ${ }^{22}$ Experience in Italy and South Korea suggests that rotation might indeed decrease rather than increase market competition. ${ }^{23}$ According to the European Commission, the requirement of a mandatory audit firm should be accompanied by other measures such as mandatory tendering in such a way that smaller and medium-sized audit firms are not precluded. The Audit Regulation introduced such a tendering process. ${ }^{24}$ However, the question remains whether smaller audit firms have sufficient incentives to participate, considering the costs of tendering, the complexity of conducting audits at PIEs, potential (unlimited) liability, the level of regulatory oversight, and the level of fees.

\subsubsection{The Rotation Requirement and Member State Options}

Article 17 of the Audit Regulation contains the main provisions on mandatory audit firm rotation. The Audit Regulation stipulates both a minimum and a maximum duration period of audit engagements. A PIE should appoint an audit firm for an initial engagement of at least 1 year, which may be renewed. Member states are given

\footnotetext{
17 Evidence for this argument is mixed, see Ewelt-Knauer et al. (2012), p 7; Cameran et al. (2005), p 40.

18 The European Commission Impact Assessment, p 175.

19 Ewelt-Knauer et al. (2012), pp 7, 26-30.

20 The European Commission Impact Assessment, p 175.

21 SDA Università Bocconi (2002); Cameran et al. (2005), p 42.

22 The European Commission Impact Assessment, p 175.

23 Ewelt-Knauer et al. (2012), p 34.

24 Art. 16(3) Audit Regulation.
} 
the option to require that the initial engagement should be for a period of more than 1 year, however.

The maximum duration for the audit engagement is 10 years. ${ }^{25}$ Member states are allowed to reduce this period. ${ }^{26}$ They are also allowed to increase the period under certain conditions. ${ }^{27}$ An extension to 20 years is allowed if a public tendering process is conducted in accordance with the Audit Regulation's requirements. Alternatively, an extension to 24 years is allowed if more than one statutory auditor is simultaneously engaged after the first period, leading to a joint audit report. In both cases an extension is only possible if the general meeting of shareholders approves the proposal for renewing the engagement. ${ }^{28} \mathrm{~A}$ further extension of at most 2 years can be granted by the competent authority, i.e. the supervisor, after a request by the PIE in exceptional cases. ${ }^{29}$

The Audit Regulation requires the outgoing auditor or audit firm to prepare a hand-over file and to provide the incoming statutory auditor or audit firm with access to all relevant information concerning the audited entity and concerning the most recent audit of that entity. ${ }^{30}$ Any information that has been transmitted to supervisors should also be made available to the incoming audit firm. ${ }^{31}$

\subsection{Mandatory Audit Firm Rotation in the Netherlands}

Prior to the adoption of the Audit Regulation, the Dutch legislator already considered introducing a mandatory audit firm rotation requirement in Dutch law. The requirement of mandatory audit firm rotation was suggested in 2012 and was subsequently adopted in national legislation for PIEs. ${ }^{32}$ The originally intended date of application of this requirement was 1 January 2014. PIEs were to be required to change from audit firm after eight consecutive years to prevent too much involvement and familiarity of the audit firm with the PIE. This proposed Dutch maximum duration of audit engagements was shorter than the 10 year default maximum period in the Audit Regulation, although the Audit Regulation also allows a shorter engagement period as a member state option. Furthermore, the Dutch requirement was planned to apply much earlier than the date on which the requirements in the Audit Regulation entered into force (i.e. 17 June 2016). It could thus be said that, in advance of the realization of the mandatory audit firm requirement in the Audit

\footnotetext{
25 Art. 17(1) Audit Regulation.

26 Art. 17(2)(b) Audit Regulation.

27 Art. 17(4) Audit Regulation.

28 Art. 17(5) Audit Regulation, which states that the extension can be done 'only if, upon a recommendation of the audit committee, the administrative or supervisory body, proposes to the general meeting of shareholders or members, in accordance with national law, that the engagement be renewed and that proposal is approved'.

29 Art. 17(6) Audit Regulation.

30 Art. 18 Audit Regulation.

31 Art. 18(2) Audit Regulation.

32 The requirement was introduced in the Audit Firms Supervision Act (Wet toezicht accountantsorganisaties; Staatsblad 2012, no. 681).
} 
Regulation, the Dutch government already showed its belief in the beneficial effects of mandatory audit firm rotation.

In light of preventing inconsistencies between the proposed requirement in the Netherlands and the coming obligation in the Audit Regulation, the date of application of the requirement in Dutch law was at first delayed from 1 January 2014 to 1 January 2016. Although the Dutch Parliament considered it necessary to implement the requirement of mandatory audit firm rotation directly, when the Audit Regulation was adopted it was finally-in the autumn of 2015-decided not have the national legislation on mandatory audit firm rotation becoming applicable at all and to have this subject regulated exclusively by the Audit Regulation.

The Dutch government did not make use of the member state options in the Audit Regulation. Thus, in the Netherlands there is no possibility to extend the maximum period for the audit engagement after 10 years. There is also no possibility for PIEs to request the national supervisor for an extension. Perhaps surprisingly, the original 8 year maximum period that was envisaged in national legislation was also abandoned. The Netherlands conformed to the 10 year default maximum period in the Audit Regulation. However, rotation of the key partner responsible for carrying out a statutory audit is required every 5 years in the Netherlands, where the Audit Regulation's default for rotation of key partners is seven years. ${ }^{33}$

Although in the Netherlands the national legislation in the final stage was abandoned, a rotation 'wave' had already occurred in anticipation of the expected deadline of - at first-1 January 2014 and-subsequently_-1 January 2016. Nowadays, the Audit Regulation grants PIEs, also in the Netherlands, a much longer period to rotate from audit firm. ${ }^{34}$ The relatively large number of audit firm rotations in anticipation of the expected national legislation has allowed us to carry out an empirical study of the effects of (mandatory) audit firm rotation.

\section{The Effects of Mandatory Audit Firm Rotation in the Netherlands}

\subsection{Research Design and Methodology}

\subsubsection{Dual Methodology}

Our empirical study of the effects of mandatory audit firm rotation in the Netherlands was carried out by using a dual methodology. It the first place, we studied the publicly available annual reports ${ }^{35}$ for the financial years 2012-2016 for companies incorporated in the Netherlands whose (depositary receipts for) shares are listed on the Dutch stock exchange Euronext Amsterdam. In addition, we conducted survey research by distributing a questionnaire among different stakeholders. By combining

\footnotetext{
33 Art. 17(7) Audit Regulation.

34 Art. 41 Audit Regulation.

35 We mean the combination of the financial statements, the management report, statements by responsible persons, and the auditor report. See Art. 4 Council Directive 2004/109/EC [2004] OJ L 390/38.
} 
these methodologies, the effects of audit firm rotation could be researched more comprehensively.

\subsubsection{Study of Annual Financial Reports, Proxies and Audit Fees}

By studying the annual reports over the financial years 2012-2016, we assessed which Dutch listed companies changed from audit firm during this period. In each financial year we examined various proxies that could possibly be an indication of the independence of the audit firm and/or the quality of the audit performed by the auditor. ${ }^{36}$ A proxy is a possible indicator that is used when the variable to be assessed is not (easily) operationalized and measured. This is certainly the case with the independence of audit firms and audit quality, as audit quality is considered to be a so-called credence good ${ }^{37}$ and because of the lack of publicly available information to assess audit independence and audit quality.

Typically, four different types of proxies are commonly used to study the effect of audit firm rotation on audit quality. ${ }^{38}$ These proxies differ from assessing audit and going concern opinions, to measuring audit failures (in retrospect) and the audited company's accrual accounting behaviour. ${ }^{39}$ We used a mixture of these types of proxies commonly used to study audit firm independence and/or audit quality. ${ }^{40}$ Specifically, we examined:

1. The return of an audit assignment by the auditor or the withdrawal thereof by the listed company, since this may indicate that the auditor or the company do not agree on the conditions or the execution of the audit assignment;

2. The lack of an unqualified opinion by the auditor (in the sense of Art. 2:393 para. 6 Dutch Civil Code), since this may form an indication of the level of 'severity' of the auditor;

3. The inclusion of an emphasis of matter in the auditor's report, since this may form an indication of the level of 'severity' of the auditor;

4. A delay in the publication of the annual reports in relation to the statutory period or the earlier announcement by the listed company, since this may be due to the level of 'severity' of the auditor ${ }^{41}$;

5. The issuance of a profit warning or recognition of an impairment by the listed company, since this may be instigated by the auditor;

\footnotetext{
36 Audit independence and audit quality are related to each other. See for example the definition of audit quality by DeAngelo (1981), p 186: 'the market-assessed joint probability that a given auditor will both (a) discover a breach in the client's accounting system, and (b) report the breach.'.

37 Knechel (2016).

38 Ewelt-Knauer et al. (2012), pp 24-30.

39 Accruals relate to the difference between reported cash flows and the accruals-based income statement.

40 We did not include a formal analysis of accruals.

41 Abma (2015), p 537.
} 
6. Whether an adjustment of accounting principles was implemented (and whether or not this was reported to the supervisor for the financial markets as 'inside information' by the listed company), since this may be instigated by the auditor;

7. The inclusion of key audit matters ('KAMs') in the audit report by the auditor, which deviates from the risks mentioned in the report of the management board and the supervisory board of the listed company, since this may suggest that the auditor and the management board and/or supervisory board disagree about the matters that were most significant during the audit of the financial statements. ${ }^{42}$

In addition, we examined (the change in) the auditor's fee in connection with the audit of the financial statements (audit fees) during the various financial years. The level (and change) of the audit fees may also give an indication of the quality of the audit, whereby it is assumed that lower fees negatively affect audit quality.

Our considerations for using these proxies and audit fees are that they are measurable and can be distilled from public data. They also tie in with the methodology used in international research discussed above. We did not have access to non-public information during our research. A drawback of (some of) the proxies we used is that they are not perfect measuring instruments, as the occurrence of a certain proxy does not necessarily demonstrate auditor independence or quality. For example, a profit warning (proxy 5) could have been instigated by the auditor, but may also be unrelated to the auditor's behaviour.

The proxies involved in our research always assume a value of 0 ('does not occur') or 1 ('occurs'). Only the examined audit fees are not encoded in our database as a digital 0/1-variable, but as a continuous variable.

For our analysis, we compared the proxies in the financial year prior to rotation of the audit firm (last year audit, 'LYA'), the financial year after rotation of the audit firm (first year audit, 'FYA') and the financial year in which the decision for rotation was taken or announced (decision year audit, 'DYA') with the other 'regular' financial years during the analyzed period 2012-2016. ${ }^{43}$ In other words, we compared the existence of circumstances that trigger one or more of the aforementioned proxies during the financial years LYA, FYA or DYA with the existence of such circumstances during the regular years (see Sect. 3.2.2 et seq.).

\subsubsection{Survey Research}

Within the survey study, we used an online questionnaire. ${ }^{44}$ The questionnaire was distributed to relevant stakeholders in September and October 2017. Among these stakeholders were (with the number of respondents in brackets):

\footnotetext{
42 Note that the requirement to disclose KAMs in the audit report for Dutch listed companies is effective as of the financial year 2014.

43 The DYA represents the year in which the general meeting of the audited company formally appoints the auditor. Since it is common practice for listed companies to elect the auditor for the current financial year, DYA is often similar to FYA. We however also observed DYAs which were not equal to FYA or LYA, probably because the competition related to the mandatory audit firm rotation forced companies to anticipate audit firm rotation early on.

${ }^{44}$ For the questionnaire and response rates, see: https://doi.org/10.17026/dans-zab-7twx.
} 
- regulators and supervisors (8);

- auditors, authorized to perform statutory audits at PIEs (hereafter PIE auditors;

73);

- auditors, not authorized to perform statutory audits at PIEs (24);

- audited companies or institutions, which are PIEs (22);

- audited companies or institutions, not PIEs (21); and

- users of annual accounts, including interest groups such as the Dutch investor association (VEB) and its members and Eumedion, which represents institutional investors (64).

The questionnaire could be filled in anonymously, so that stakeholders could feel free to answer truthfully. The questionnaire contained 25 questions relating to the maximum duration for statutory audit engagements, the requirements on the cooling-off period and aspects of the regular and mandatory (re)tenders as included in the Audit Regulation. A total of 278 respondents answered one or more questions. 171 respondents fully completed the survey (62\% of the 278 ). The results were examined statistically (if there were sufficient observations) and/or qualitatively.

\subsection{Research Outcomes Based on Yearly Financial Reports 2012-2016}

\subsubsection{Number and Types of Rotations}

In total, 74 out of 114 Dutch listed companies rotated from audit firm at least once during the period under review (financial years 2012-2016). In addition, five companies rotated a second time during this period - and thus at least once 'voluntarily'. ${ }^{45}$

The development of audit firm rotation started mainly from (the audit of the annual financial statements for) the 2014 financial year, i.e. the calendar year 2015. Prior to that, only $13 \%$ of the total number of rotations had taken place. With regard to some of the rotations, explicit justification has been disclosed by the listed company referring to the (proposed) legislation that would make this compulsory. Figure 1 shows the number of rotations per financial year.

\subsubsection{The Proxies: Few Relate to Audit Firm Rotation}

We present an overview with univariate results in the Annex. For most of the individual proxies that we used, no statistical relationship with (mandatory) firm rotation exists. The only exception is the fifth proxy: issuing a profit warning or the recognition of an impairment. This was the case in $14 \%$ of the annual financial

\footnotetext{
45 Strictly speaking, all rotations during the period under review were voluntary. However, as discussed earlier in Sect. 2.2, there are good reasons to consider all rotations in this period mandatory, since the vast majority of Dutch listed companies already rotated from audit firm in anticipation of the national requirement which required PIEs to rotate from audit firm.
} 
statements (i.e. 48 times) in the financial years during the whole period under review (2012-2016). For this proxy we have performed a regression analysis using a logit model. With a logit model, the dependent variable takes only two values. In this case, it is the occurrence or non-occurrence of the profit warning or impairment. Using the model, the probability can be estimated that a profit warning or impairment occurs in the different types of audit years (LYA, FYA or DYA compared to other years). The results of this analysis are shown in Table 1.

The results show that the probability of a profit warning or impairment is significantly lower in a LYA than in an audit year that does not qualify as LYA ('a nonLYA'). ${ }^{46}$ For the other special types of audit years (FYA and DYA), no statistical relationship with audit firm rotation could be established.

Our initial hypothesis was that auditors would have a stricter attitude, i.e. a more independent or less familiar attitude towards the audited company in a LYA, since in that year there is not much more to be gained with customer-friendliness and there is still a reputational risk in the event of audit failures, e.g. in case of undiscovered fraud. This could result in an auditor who exerts more pressure on (the management of) an audited company to issue a profit warning or to recognize an impairment loss. On the basis of the results depicted in Table 1, it can be doubted whether this hypothesis can still hold true; the likelihood of a profit warning or impairment occurring in a LYA is significantly lower than in other audit years (non-LYA). It might suggest that the interest of performing a good audit in DYA is lower, as the auditor knows that its appointment will not be renewed. This conclusion could be a point of attention for audit firms, users of annual financial statements and the Dutch supervisor of audit firms, as well as the Netherlands Authority for the Financial Markets (hereafter AFM).

Regarding the other proxies, some findings are worth mentioning, even though a formal or statistical relationship with audit firm rotation could not be established. In at least 17 FYAs (23\%), the FYA itself (and therefore audit firm rotation) was considered by the auditor as KAM in the audit report (proxy 7). ${ }^{47}$ In eight of these cases, this concerned a company being part of the AEX index. ${ }^{48}$ In six of these fifteen cases (40\%), the KAM was presented more prominently in the FYA than the other KAMs by mentioning it first in the audit report, which could possibly be interpreted as that FYA being regarded as the most important KAM that year. ${ }^{49}$ In virtually all cases where the FYA has been included as a KAM by the auditor, the acquisition of knowledge regarding the company, its environment and internal risk management and control systems is the most important part of the FYA in the KAM

\footnotetext{
46 Only in case of LYA, the null hypothesis that no relationship exists may be rejected on a $95 \%$ confidence interval. The results suggest that the probability that a profit warning or impairment occurs in a LYA is significantly lower than in other years.

47 We note that the regulatory framework regarding the disclosure of KAMs in the audit reports changed significantly during 2012-2016.

48 The AEX index, derived from the Amsterdam Exchange index, is the stock market index composed of the 25 companies with the largest market capitalization on Euronext Amsterdam.

49 See Standard 705 of the International Standards on Auditing (ISA).
} 


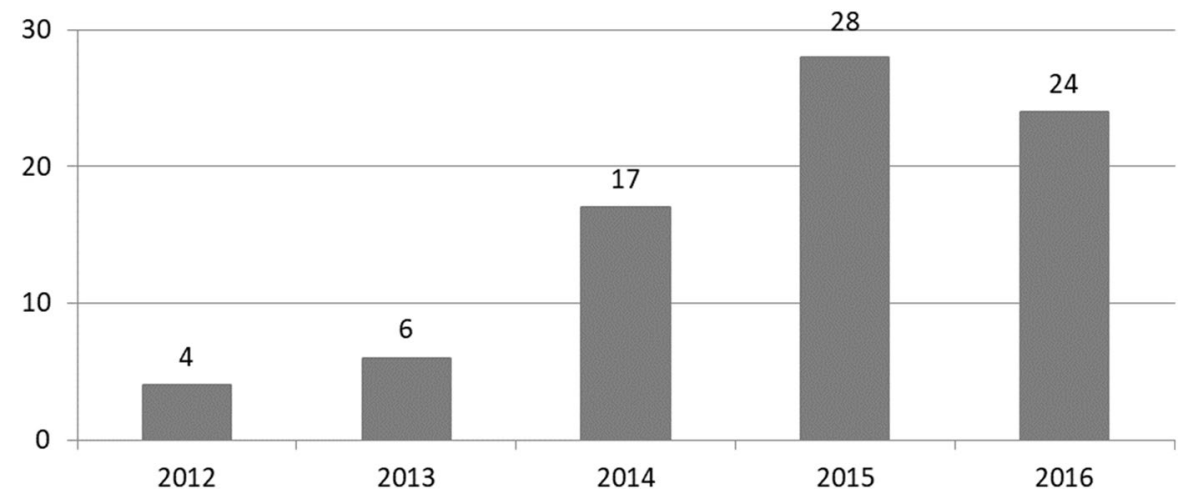

Fig. 1 Number of audit firm rotations per financial year

Table 1 Logit regression results on proxy 5 , issuing a profit warning or recognizing an impairment

\begin{tabular}{llll}
\hline & Sig & Coëfficiënt & Exp (Coëfficiënt) \\
\hline FYA & 0.071 & -1.068 & 0.344 \\
LYA & 0.034 & -1.075 & 0.341 \\
DYA & 0.205 & 0.608 & 1.837 \\
Constant & 0.000 & -1.552 & 0.212 \\
\hline
\end{tabular}

(14 times). This is followed by the audit of the opening balance (12 times) and the discussion with the previous auditor (11 times).

\subsubsection{Audit Fees: An Anomaly in First Year Audits}

In the period under review we examined the auditor's remuneration related to the audit of the financial statements of a company (the audit fees). Audit fees must be distinguished from an auditor's total remuneration, which may also include fees for other work performed by an audit firm (e.g. tax advisory services or other non-statutory audit services). Note, however, that (lower) audit fees may be compensated with (higher) fees for non-audit services. But since the Dutch legislator introduced a prohibition for all types of non-audit services to audited PIEs in 2013, this risk should be largely mitigated. ${ }^{50}$

In general, we found an upward trend in audit fees; audit fees increase every year. An exception to this is the amount of audit fees in the FYA. We found that the median change in audit fees in an FYA compared to the previous year (LYA) is

\footnotetext{
${ }^{50}$ Art. 24b Audit Firms Supervision Act. The prohibition introduced in the Audit Firms Supervision did not only enter into force at an earlier moment than the provisions introduced in the Audit Regulation with regard to providing non-audit services to audited PIEs; the prohibition in Art. 24b of the Audit Firms Supervision Act is also more stringent.
} 


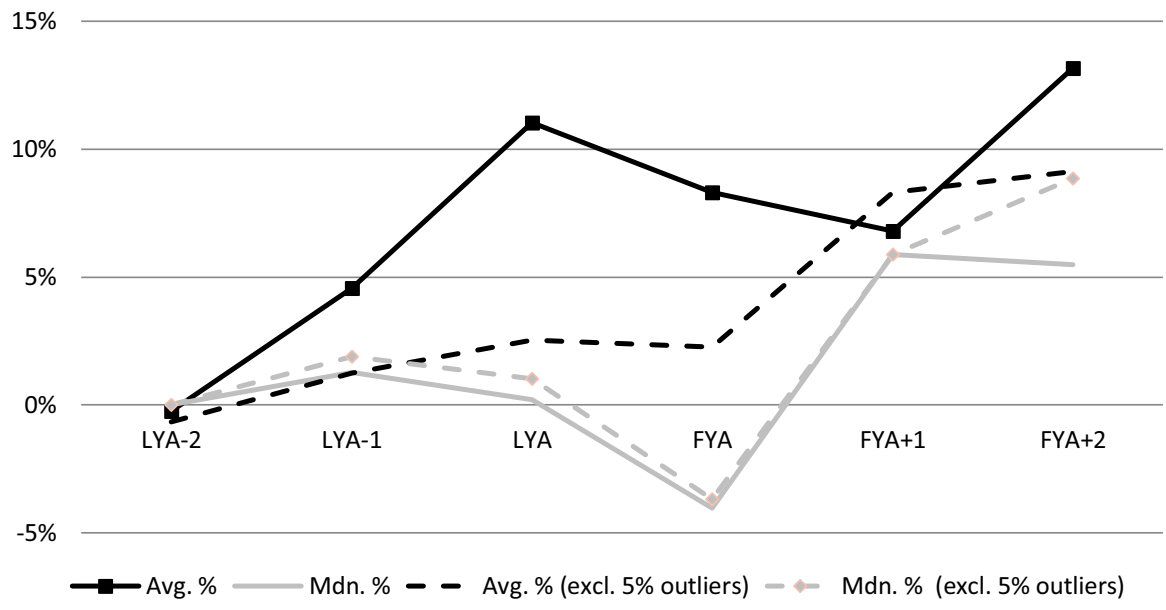

Fig. 2 Development of audit fees-compared to previous audit years (\%)

$-4.04 \%$ versus $0.37 \%$. The changes over the different types of audit years are shown in Fig. 2.

For Dutch companies in the AEX index, the average (median) of the change in audit fees in FYAs was significantly lower than for other Dutch listed companies: $-9.4 \%(-6.6 \%)$ versus $16.3 \%(0.9 \%)$. In two other studies this is referred to as the 'trophy client effect'. ${ }^{51}$ For audit firms, so-called AEX companies seem to be important clients ('trophies'), which means that the audit firm seems to be willing to offer (at least for the FYA) lower fees in order to be given the assignment for conducting the statutory audit.

Finally, it is remarkable that in at least one case it is explained during the general meeting of the company that audit firm rotation has been used to reduce the scope of the audit engagement (the audit scope) to the minimum of activities that are required. In that case, the scope — and therefore: the number-of statutory audits of other subsidiaries of the group of the listed company was limited to the required minimum level. This may be an adverse consequence of audit firm rotation and it may have occurred in other cases of audit firm rotation as well, without third parties being well informed. These kinds of adverse consequences of audit firm rotation should be taken into account when evaluating the Audit Regulation as well.

\subsection{Survey Research Outcomes}

\subsubsection{Requirements in the Audit Regulation Largely Considered Desirable}

The package of requirements introduced by the Audit Regulation and the choices made by the Dutch legislature are not undisputed. We therefore questioned the

51 Abma (2017); Kevelam et al. (2017). 


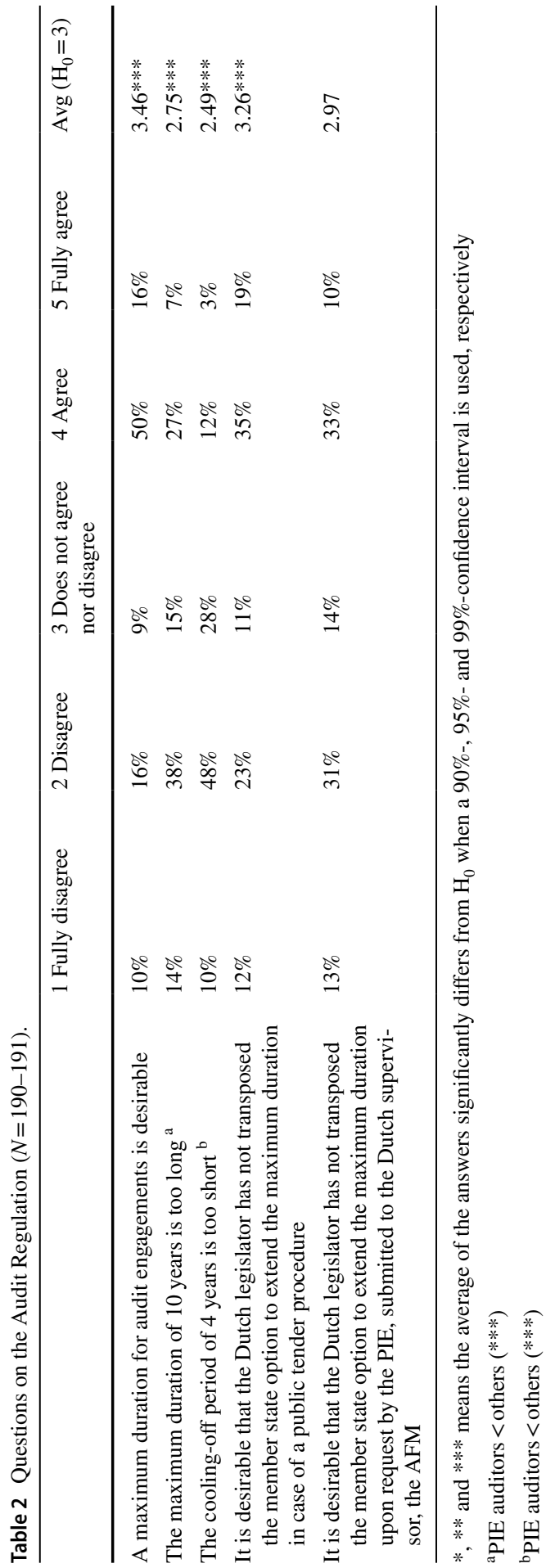


respondents to what extent they endorse the individual requirements and choices. We examined whether the averages of the answers given by the respondents differed significantly from the average value of 3 ('neither agree nor disagree') using a twotailed t-test. The results are shown in Table 2.

A statistically significant majority of the respondents consider a maximum period for statutory audits to be desirable. This is perhaps surprising, given that a substantial proportion of the respondents consist of auditors, who in general have a less positive attitude towards the requirement of mandatory audit firm rotation. The maximum duration of 10 years of an audit engagement, as stipulated by the Audit Regulation, was not judged as being too long by a statistically significant majority. This could be an indication that a stricter and shorter maximum period for audit engagements is not considered desirable. Compared to other respondents, a significant amount of PIE auditors disagreed with the statement that the maximum duration of 10 years of an audit engagement is too long, according to a breakdown of the background of the respondents (footnote a of Table 2). This indicates that PIE auditors are probably in favour of a longer maximum period for audit engagements than other respondents.

A cooling-off period of 4 years is not seen as too short by a significant majority of the respondents. Again, PIE auditors significantly disagreed more with this statement than other respondents (footnote b of Table 2). Based on these results, there seems to be no reason to introduce a longer cooling-off period in the Audit Regulation.

With regard to the two member state options, we questioned to what extent the respondents agreed with the choices made by the Dutch legislator not to transpose these options in Dutch legislation. A statistically significant majority of the respondents endorsed the decision not to allow the rotation period to be extended to 20 years in the event of a public tender. Regarding the choice not to allow the AFM to extend the audit engagement by 2 years following a request from the PIE, divergent answers were given by respondents.

Some of the respondents added some noteworthy explanations for their answers. For example, a respondent pointed out the need for flexibility in relation to the oligopoly of the Big Four audit firms regarding the previous subjects:

In order to maintain flexibility and with due regard to the public interest, it is desirable that, possibly after consultation with the AFM, the cooling-off period may be reduced or the maximum period may be extended.

Another respondent also points out that the supervisory board or the audit committee of the company should be responsible for determining the maximum duration of the audit engagement. This respondent is in favour of a maximum period with a comply-or-explain nature. Although these respondents seem to concur with the principle of the Audit Regulation that the duration of the audit engagement is desirable, they prefer more flexibility in the requirements of audit firm rotation than currently exists under the current rules of the Audit Regulation.

Respondents also describe the dynamics surrounding the rotation for an audit firm and the associated costs thereof: 


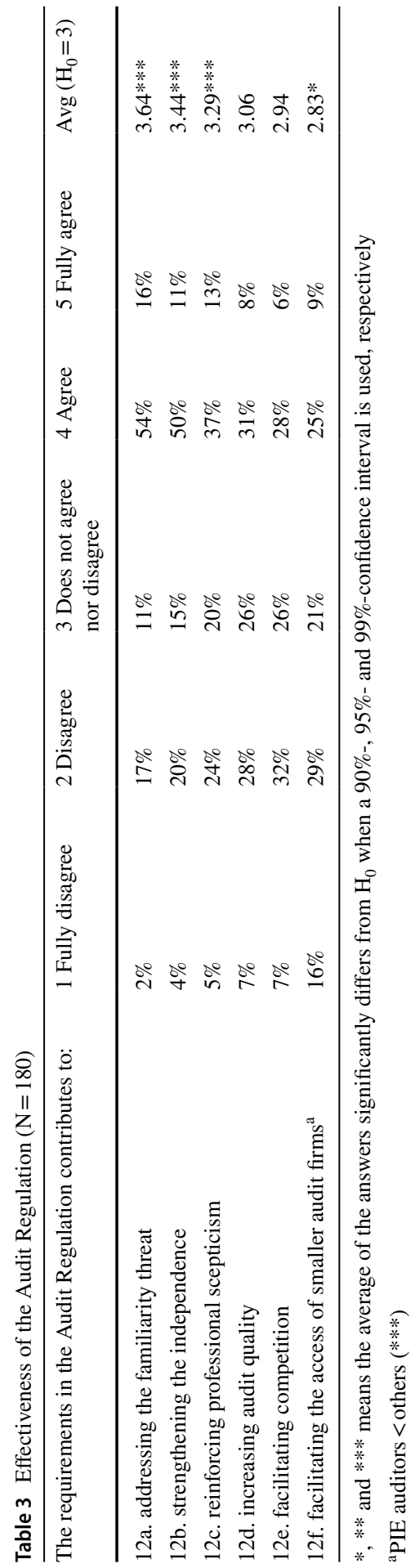


In practice, 3 years are required as an external auditor to properly understand an assignment and the dynamics of an organization. Then there is another 4 years of a balanced situation, and in the last 2 years there is already a special dynamic of the impending farewell.

And:

There are huge costs associated with the rotation [...] There also seems to be a high level of lowballing. This is evident not only from the realization of newly acquired orders (often 50\% below cost at PIEs in the first year!), but also on the feedback from lost proposals, the reason for which is often the price.

All in all, it seems that although the majority of the respondents consider a maximum duration of audit engagements desirable, some of the respondents suggest that the costs associated with mandatory audit firm rotation justify a less rigid approach in the Audit Regulation. The desirability of such measures are worth being taken into account when evaluating the current audit rotation rules of the Audit Regulation.

\subsubsection{Not All the Goals of the Audit Regulation are Met}

We questioned the respondents to what extent they believe that the measures set out in the Audit Regulation contribute to the realization of their intended objectives (Sect. 2.1.1). The results are shown in Table 3.

The results in Table 3 show that, according to a statistically significant majority, the first three objectives of the Audit Regulation are achieved with the package of the introduced requirements. These requirements intend to limit the familiarity threat, and to increase the independence and professional-critical attitude of the auditor. The respondents do not agree on the contribution of the requirements to increasing the quality of the audit and promoting competition in the market of statutory audits. Finally, a significant majority of respondents believe that the requirements do not contribute to promoting the access of non-Big Four audit firms in the market of statutory audits at PIEs. PIE auditors are even more convinced that the market of statutory audits at PIEs remains in the hands of the Big Four audit firms. According to the respondents, mandatory audit firm rotation did not enhance auditor choice.

There were some notable explanations about the perceived effectiveness of the Audit Regulation. Regarding the relationship between the positive and negative effects of audit firm rotation, it was for instance stated:

The risk of a lack of independence [...] does not outweigh the loss of knowledge as a result of rotation, the lack of motivation of the auditor in the last 2 years of the audit, the extra efforts in the work of the new auditor and the time it takes for the new auditor to come to the same level of knowledge and insight as the previous auditor.

A respondent drew attention to the tension between the quality of the audit and the consequences of competition for audit fees: 
The competition leads to low fees, but a desire to increase quality does not fit with increasing budget pressure.

With regard to competition in the market for statutory audits for PIEs and barriers for entering that market, it was noted that:

The limited number of audit firms that can audit PIEs is far too small, as a result of which they have obtained a legally protected monopoly position.

Furthermore:

It promotes access because non-Big Four firms are invited to participate more often in a tender, even though the actual choice still often goes to a Big Four firm.

\subsubsection{Adverse Effects: Lower Quality of the First Year Audit?}

We assessed whether there is a difference in the quality of the audit in the different types of audit years that may be attributed to (mandatory) audit firm rotation. We have differentiated between FYAs, LYAs and DYAs. These special years have been examined in comparison with statutory audits conducted in other financial years.

Regarding the special years FYA, LYA and DYA, we questioned respondents whether or not compared to the 'normal' audit years:

1. the quality of the audit is higher;

2. the chance of errors during the audit is higher;

3. the statutory audit fees are higher;

4. the costs to be incurred in the context of the statutory audit are higher; and

5. the auditor is more independent.

The results of the answers to the questions regarding FYA are included in Table 4. The matrix shows that a statistically significant majority of the respondents are of the opinion that the quality of the statutory audit is not higher in a FYA. However, according to the respondents, the probability of errors during the audit in FYAs is higher. This result may be explained as follows. Although a new auditor can have a fresh perspective, he is unfamiliar with the listed company and its environment, and there are considerable costs for the new auditor to settle in. A statistically significant majority of the respondents endorse these higher costs. The annual financial report analysis also showed that auditors sometimes present a FYA as a KAM (Sect. 3.2.2). A further breakdown by the type of respondents shows that PIE auditors make a significantly more negative assessment of the claim that the quality of the audit is higher in a FYA than other respondents (see footnote a in Table 4).

The previous results are hard to reconcile with the desire to increase the quality of the audit by requiring audit firm rotation. This is even more so in light of the findings of lower audit fees for AEX companies in FYAs (Sect. 3.2.3).

We also investigated the quality of audits in a LYA. The results are shown in Table 5 . 


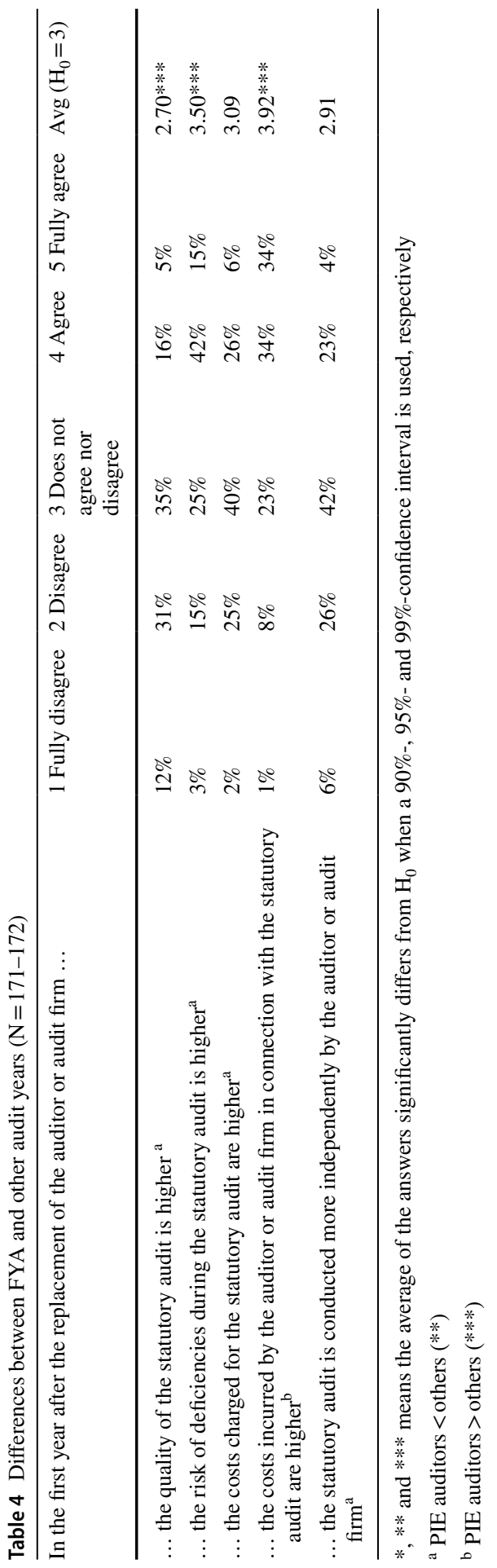




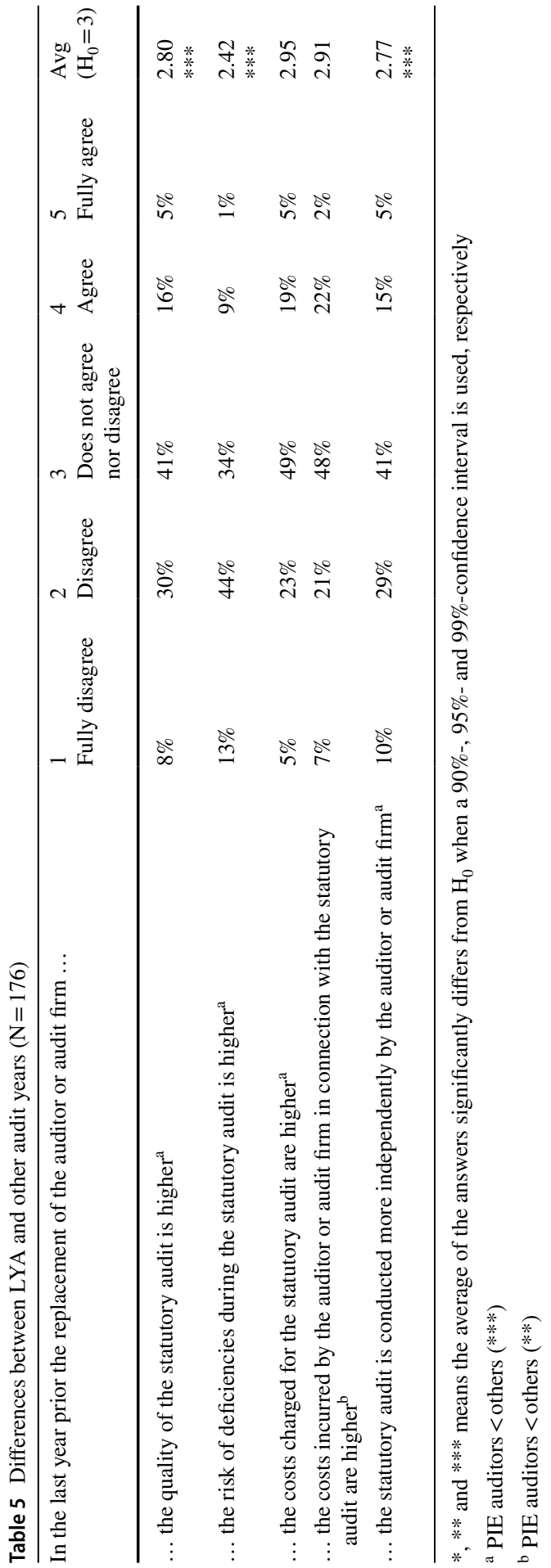


The matrix shows that a statistically significant majority of the respondents believe that the quality in a LYA is not higher. Nor is the likelihood of deficiencies during the statutory audit considered to be higher. According to a significant majority of the respondents, the auditor does not act more independently in the LYA compared to other audit years. This is not in line with our initial hypothesis that auditors would act more independently in a LYA, as there is not much to be gained from customer-friendliness and there is still a reputational risk for the auditor in the event of later discovered audit failures. In our analysis of annual financial reports, we also found indications that the quality of audits and the independence of auditors are not higher in LYAs, but rather lower (Sect. 3.2.2).

A further breakdown by the type of respondents shows that PIE auditors are more pronounced than other respondents in their rejection of the statements that the quality and the likelihood of deficiencies in a LYA are higher and that the auditor is more independent (footnote a of Table 5).

Finally, we asked the respondents similar questions about the DYA in the questionnaire. If there is a deviation between the LYA and DYA, there appears to be no relevant difference in the quality of the statutory audit between DYA and other audit years.

\subsubsection{Improvements Regarding the Transition Between Incoming and Outgoing Auditor}

We questioned stakeholders whether improvements could be made in the process of transferring information and responsibilities from the outgoing auditor or audit firm to the incoming auditor or audit firm, and if so, with regard to which aspects. As discussed, a hand-over file prepared by the outgoing auditor is seen by the European Commission as an important tool for preventing a loss of knowledge resulting from mandatory audit firm rotation (Sect. 2.1.2). Respondents could choose from the following answer options:

1. I do not see any possibilities for improvement;

2. The (collegial) consultations between the former auditor or audit firm and the successor auditor or audit firm;

3. The hand-over file with the proposed audit process provided by the former auditor or audit firm to the successor auditor or audit firm;

4. Providing relevant audit documentation in a hand-over file to the successor auditor of audit firm;

5. The successor auditor or audit firm attending meetings between the former auditor or audit firm and representatives of the audited company or organization, e.g. with members of the Board or audit committee;

6 . The successor auditor or audit firm taking knowledge of the risk analysis of the former auditor of audit firm;

7. The successor auditor or audit firm conducting a review of the audit file;

8. No opinion;

9. Other. 
For the answer options listed above, we followed the terminology used by the Dutch Royal Netherlands Institute of Chartered Accountants. ${ }^{52}$ The results are depicted below in Fig. 3 .

The results show that most respondents saw room for improvement, somewhat evenly distributed between the different topics. The hand-over file was seen by most respondents as an area for improvement. This is consistent with the European Commission's remark in the European Commission Impact Assessment that a handover file is important. However, there are some dissenting voices. For example, one respondent remarked:

An extensively regulated transition process is far off from the idea that the new audit firm has a fresh perspective.

A good hand-over file may thus be useful, to the extent that it does not prejudice a potential fresh perspective. Currently, the Audit Regulation requires a hand-over file (see Sect. 2.1.3), but does not regulate its contents extensively. Future research may be beneficial to find out whether and how the transition process-and the use of a hand-over file-could further be improved.

\section{Implications of the Dutch Experience for the EU and its Member States}

\subsection{No Change in Audit Regulation Required}

The questionnaire among Dutch stakeholders shows statistically significant support for the mandatory audit firm rotation requirement in the Audit Regulation. Although this requirement was seen as controversial at the time of its adoption, it is now considered desirable by various stakeholders, including auditors themselves. Hence, this empirical study shows no support for the abolition or a softening of this requirement. Regarding the transition process between the incoming and outgoing audit firm, our survey suggested several areas for improvement. Further research is required to find out whether this should have any consequences for the Audit Regulation or supervisory practices.

\subsection{Aiming for High Quality of First and Last Year Audits}

Our research suggests a higher probability of deficiencies in FYAs. This undermines the goal of improving audit quality through auditor independence. This risk may have been underestimated somewhat by the European legislator. Although the European Commission Impact Assessment mentioned the costs for audit firms to gain firm-specific knowledge of a PIE, and the costs for the PIE to familiarize the new

\footnotetext{
52 Guidance paper 1134 of 5 November 2015, www.nba.nl/globalassets/wet--en-regelgeving/nba-handr eikingen/nbahandreiking_1134_samenwerking_voorgaande_en_opvolgende_accountant.pdf.
} 


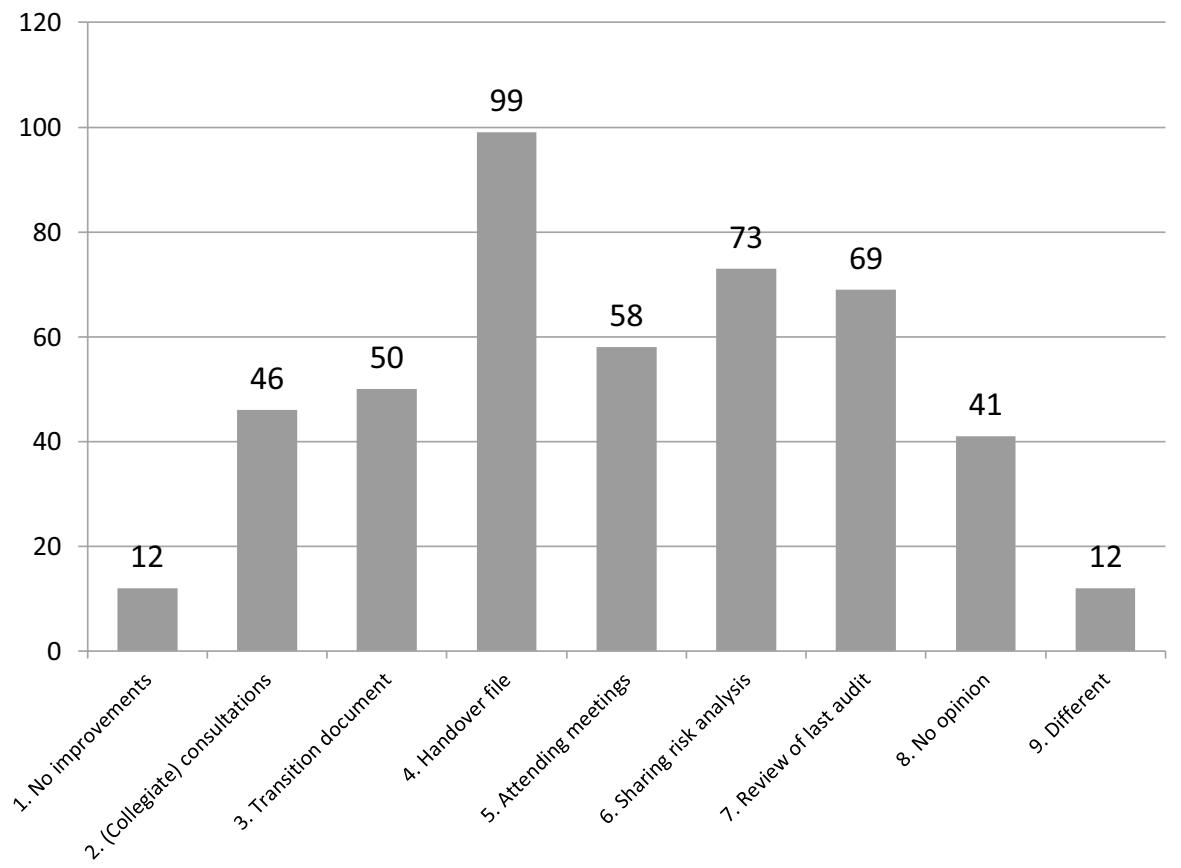

Fig. 3 Improvements in transition between incoming and outgoing auditor

auditor with its operations, it seemed that the European Commission was confident that carefully designed rules could sufficiently mitigate these risks. The discount on their audit fees that audit firms provide to lucrative larger PIEs - the trophy client effect-may exacerbate the negative effect on audit quality. This is because the discount may lead to less man-hours being spent on the audit to prevent lower profitability, whereas it is expected that a FYA - especially in the case of large PIEsprobably requires more efforts (compared to other financial years) to achieve the same level of audit quality.

What can be done about the potential lower quality of FYAs? In our view, the role of auditors and audit firms, on the one hand, and the role of supervisors, listed companies and investors, on the other, should be distinguished. Auditors themselves have a professional responsibility to offer high quality audits. Audit firms are not only obliged to provide an environment making it possible for auditors to accomplish their professional duties, but audit firms are also required to have an effective assurance quality system in place. ${ }^{53}$ In the Netherlands compliance with the professional standards by auditors can be enforced in disciplinary proceedings, whilst compliance with the requirements applicable to audit firms is supervised by the AFM. The results of our research indicate that in order to substantiate the responsibilities of auditors and audit firms, investing a sufficient amount of resources, especially in the first period of the engagement, is highly desirable. Moreover, an intensive working

53 Art. 24a and further, and Art. 29 Audit Directive. 
relationship with the PIE is crucial in this stage. Audit firms may follow the practice of some Dutch audit firms which consider FYAs a KAM.

With regard to the enforcement of the responsibilities of auditors and audit firms, PIEs, supervisors and investors have a role. The boards of PIEs-and, consequently, ultimately investors - should be careful in attaching too much importance to audit fees, i.e. low or lowering audit fees should not be the most important selection criterion. This is, however, a consequence of the competition between audit firms to acquire clients during the audit rotation process and an inherent risk of a system in which the audit firm is selected and paid by (the general meeting or representatives of) the audited entity. Furthermore, the boards of PIEs could consider, as good practice, to report on the quality of FYAs and the measures that have been taken in relation to that in the management report.

Regarding investors, it is recommended for them to increase their awareness and critical assessment of audit reports in FYAs. Investors could increase the possibility of discussing the audit quality, in particular with regard to a FYA, with the boards of PIEs and with the auditor at general meetings, assuming the auditor is present at the general meeting, which is common practice for Dutch listed companies. ${ }^{54}$ Investors should also ask for more awareness for the risk of lowballing during the general meeting in which the appointment of the audit firm is on the agenda; we note, however, that investors may have (financial) incentives to lower the costs of audit fees.

Finally, there is a role for the supervisors of audit firms. The results of our research suggest that supervisors could pay special attention to FYAs. Critical assessments of the performance of auditors and audit firms by the supervisors of FYAs may reduce the risk that audit firms offer higher discounts on their audit fees to specific companies (the trophy client effect) than from a perspective of enhancing high audit quality which would be desirable. Supervisors could also assess the performance of auditors and audit firms in the years in which the audit fees are significantly lower than other years to mitigate some of the adverse consequences of the current system in which the audited entity seems to take into account the level of audit fees in their considerations of selecting an auditor firm.

The European Commission suggests that a good hand-over file provided by the outgoing auditor could mitigate quality problems in the FYA for the incoming audit firm. A more comprehensive hand-over file was seen as desirable by the largest number of respondents in our questionnaire. However, such an enhanced hand-over file should not be an impediment to a fresh perspective. Based on the outcomes of our survey, it seems that improvements in the regulation of the transition process are possible, but further research on how this can be achieved is necessary.

In our study of the annual financial statements of Dutch PIEs, we found that the quality of LYAs may also be lower. However, this result is not as robust as the perceived lower quality of FYAs, given that the result was driven by only one proxy, i.e. the issuance of a profit warning or the recognition of an impairment. A lower

\footnotetext{
54 Art. 117(5) of Book 2 of the Dutch Civil Code and best practice provision 4.1.9 of the Dutch corporate governance code.
} 
incidence of these events in LYAs could have other causes than lower audit quality. Further research is necessary as to whether and why mandatory audit firm rotation may also have an impact on audit quality in LYAs.

\subsection{Market Structure and Market Failures}

Our empirical study shows that in the Netherlands the Audit Regulation's goals regarding improving market competition in the market for statutory audits and lowering barriers to market entry have not been met. The market for statutory audits is as concentrated as it was, being dominated by the Big Four. What are the implications of this finding for the EU? In our view, it is not very likely that the mandatory audit firm rotation requirement in the Audit Regulation can be designed in such a way that the competition goals can be met. Arguably, the concentrated market structure is a result of economic forces and the societal call for public regulation and oversight, resulting in significant - and increasing — compliance costs for audit firms. Smaller audit firms may lack the scale to allot these costs to sufficient audits, or may lack a sufficient network to consider bidding for an audit engagement of a company with a group structure consisting of subsidiaries acting globally or in various jurisdictions. Furthermore, aspects of unlimited civil liability for audit firms, regulatory oversight and the costs of regulation and lower audit fees, may discourage smaller audit firms. In particular with regard to the statutory audits of PIEs, economies of scale seem to be necessary. A recent development in the UK, where Grant Thornton UK LLP announced that it was leaving the market for big company audits stating that it is too difficult to compete with the Big Four, supports this conclusion. ${ }^{55}$ Also in the Netherlands, audit firms leave the market for statutory audits of PIEs. ${ }^{56}$

In our research we did not aim to solve the concerns raised in the broader discussion of addressing failures in the market for statutory audits. We believe the mandatory audit firm rotation requirement can only play a very limited role in addressing market failures. That is not to say that the requirement of mandatory audit firm rotation in itself is the sole and sufficient measure for improving the quality of statutory audits. Concerns with regard to the quality of audits remain. Recently, the International Forum of Independent Audit Regulators identified problems in $40 \%$ of the audits they inspected. ${ }^{57}$ Suggestions have been made to break up the Big Four, ${ }^{58}$ to split off conducting statutory audits from other services and to change the way auditors are paid, thus ensuring auditors' independence.

\footnotetext{
55 See Maddison Marriage, 'Grant Thornton exits audit market for big UK companies', Financial Times, 29 March 2018 (online) ('The firm [Grant Thornton, authors] also worried that its inability to challenge the Big Four for FTSE 350 contracts-which often came down to its lack of extensive experience in this area-was bad for the morale of staff attempting to win these contracts.').

56 Grant Thornton and Accon AVM already left the market for statutory PIEs in 2019. And also Baker Tilly recently announced that it was leaving this market as of 1 January 2020 at the latest.

57 IFIAR, Survey of Inspections Findings 2017 (IFIAR 2018, www.ifiar.org).

58 See e.g. 'What the public should expect from auditors', Financial Times, 14 March 2018 (online).
} 
Although with regard to the pros and cons of these suggestions the discussion has only started and the outcome is hard to predict, one thing seems to be certain. Despite the introduction of the mandatory audit form rotation requirement in European legislation in 2016, a fierce debate on the incentives and potential legislative measures for ensuring audit quality will continue in the coming years.

\section{Conclusion}

In the wake of the financial crisis of 2007/2008, the Audit Regulation introduced mandatory audit firm rotation for PIEs. The preamble to the Audit Regulation mentions several aims to be achieved with the introduction of this requirement. The first is to reduce the 'familiarity threat' that looms in case of long audit engagements. This means reducing the risk that the auditor is too sympathetic to the interests of the company when in a close and long relationship, and the auditor lacking a fresh view to suggest improvements. Related goals mentioned in the Audit Regulation are therefore reinforcing professional scepticism and auditor independence. This should result in higher audit quality. Finally, mandatory audit firm rotation aims to improve the market for statutory audits, which is currently dominated by the Big Four. Market structure would improve by broadening the choice of statutory auditors and audit firms for PIEs and would improve by increasing competition.

In this article, we have described the outcome of our research into the effects of mandatory audit firm rotation in the Netherlands, with a particular focus on Dutch listed companies. Even though the Audit Regulation only required audit firm rotation as of 2020/2023, we have been able to examine these effects due to the particularities of the Dutch context. The Dutch legislator planned to introduce a stricter mandatory audit firm rotation regime in national legislation. In anticipation of this legislation, which was originally expected to apply as of 1 January 2014 and in a later stage as of 1 January 2016, many Dutch listed companies already rotated from audit firms. Eventually, the specific Dutch approach was abandoned and the Netherlands conformed to the rules of the Audit Regulation. The Netherlands did not use member state options to extend the maximum duration of audit engagements. Hence, mandatory audit firm rotation is required in the Netherlands after an audit engagement with a maximum duration of 10 years.

The effects of mandatory audit firm rotation have been studied by examining the annual financial reports of Dutch listed companies over the financial years 2012-2016 (which included 74 rotations), and by conducting a survey among stakeholders. We have concluded that there is broad support for the mandatory audit firm rotation requirement in the Audit Regulation. Although the measures were seen as controversial at the time of their adoption, they are now considered desirable by various stakeholders, including auditors themselves. 
Mandatory audit firm rotation appears to have resulted in some adverse effects. Most notably, our study shows a higher probability of errors in so-called FYAs (first year audits). This seems to be one of the adverse consequences of the competition between audit firms that was initiated by the introduction of mandatory audit firm rotation and inherent in a system in which the audited entity is authorized to select and pay the audit firm. To address this concern, we have made suggestions to all relevant stakeholders (companies, audit firms, supervisors and investors), including the recommendation to supervisors to critically assess potential indications for lowballing during FYAs. The Audit Regulation's goals to improve the market for statutory audits have so far failed. The market in the Netherlands was, and still is, dominated by the Big Four. Smaller audit firms have not been able or willing to enlarge their market share of audit engagements for PIEs. In our view, it is not very likely that the mandatory audit firm rotation requirement in the Audit Regulation can be designed in a such a way that this will change, as the current market structure with the dominance of four global audit firms is a consequence of economic forces requiring economies of scale. A broader discussion about concerns and possible reforms in the market for statutory audits continues to be necessary. Mandatory audit firm rotation has only a very limited role to play in this respect.

Acknowledgements Funding was received by the Vereniging van Effectenbezitters/European Investors to collect data and to cover printing, travel and salary costs.

Open Access This article is licensed under a Creative Commons Attribution 4.0 International License, which permits use, sharing, adaptation, distribution and reproduction in any medium or format, as long as you give appropriate credit to the original author(s) and the source, provide a link to the Creative Commons licence, and indicate if changes were made. The images or other third party material in this article are included in the article's Creative Commons licence, unless indicated otherwise in a credit line to the material. If material is not included in the article's Creative Commons licence and your intended use is not permitted by statutory regulation or exceeds the permitted use, you will need to obtain permission directly from the copyright holder. To view a copy of this licence, visit http://creativecommons.org/licen ses/by/4.0/.

\section{Annex}

See Table 6. 


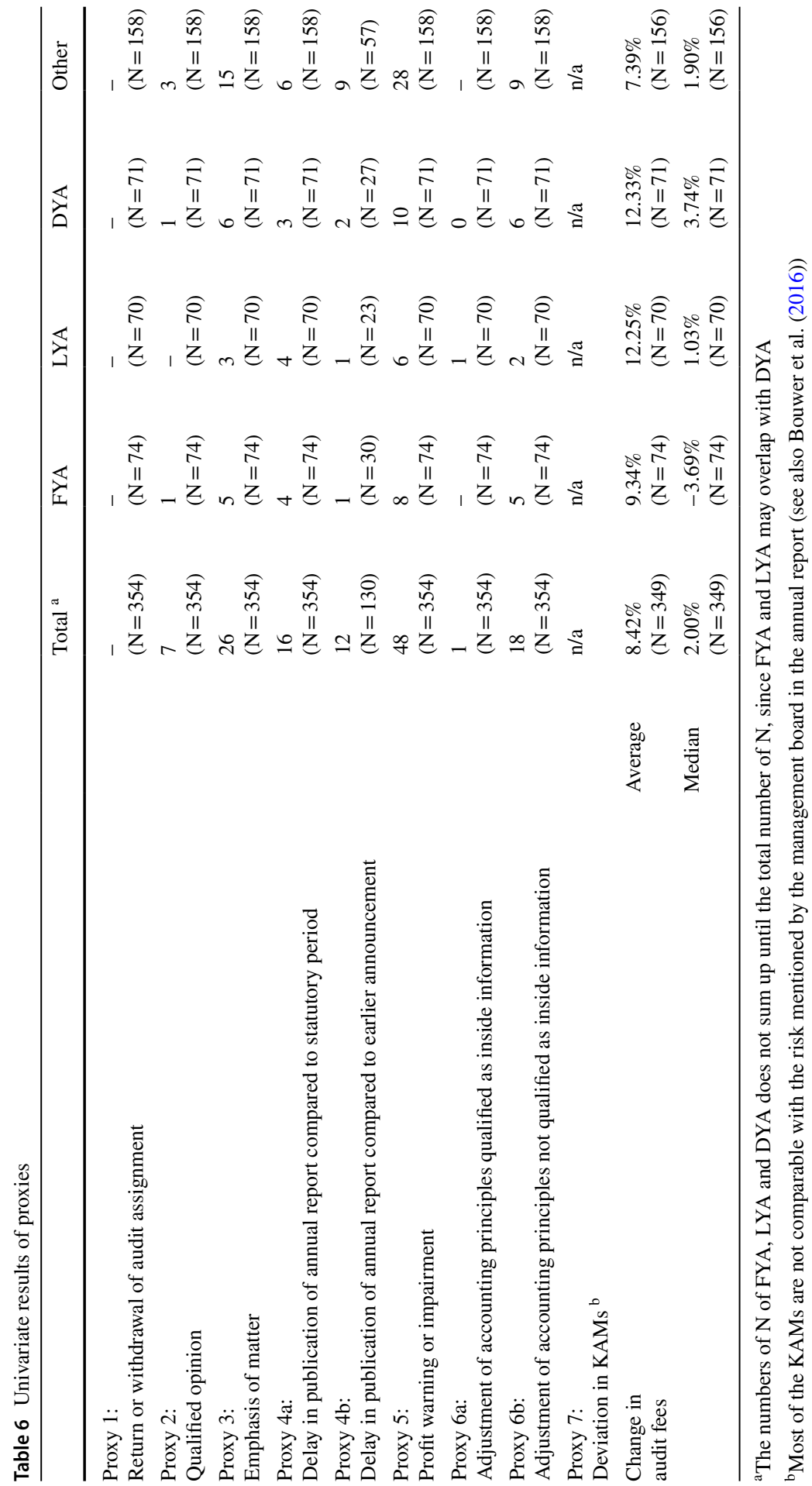




\section{References}

Abma R (2015) Kroniek van het seizoen van jaarlijkse algemene vergaderingen 2015. Ondernemingsrecht 2015/105. An English version is available at www.eumedion.nl (Evaluation of the 2015 AGM Season)

Abma R (2017) Kroniek van het seizoen van jaarlijkse algemene vergaderingen 2017. Ondernemingsrecht 2017/126. An English version is available at www.eumedion.nl (Evaluation of the 2017 AGM Season)

Arel B, Brody RG, Pan K (2005) Audit firm rotation and audit quality. CPA J 75(1):36-39

Bouwer AJ, Eimers PWA, Langendijk HPAJ (2016) De kernpunten uit de uitgebreide controleverklaring in relatie tot de risico's in het bestuursverslag en de schattingen en oordelen in de toelichting. Maandblad voor Accountancy en Bedrijfseconomie 90(12):503-502. https://doi.org/10.5117/ mab.90.31207

Cameran M, Merlotti E, Di Vincenzo D (2005) The audit firm rotation rule: a review of the literature. Working Paper, Bocconi University. https://papers.ssrn.com/sol3/papers.cfm?abstract_id=825404. Accessed 11 June 2020

Dao M, Pham T (2014) Audit tenure, auditor specialization and audit report lag. Manag Audit J 29(6):490-512

DeAngelo LE (1981) Auditor size and quality. J Account Econ 3(3):183-199

Ewelt-Knauer C, Gold AH, Pott C (2012) What do we know about mandatory audit firm rotation?. Institute of Chartered Accountants of Scotland, Edinburgh

Hoyle J (1978) Mandatory auditor rotation: arguments and alternative. J Account 145(5):69-78

Kevelam W, Ter Hoeven R, Brouwer T (2017) Accountantshonoraria in de jaarrekening. Maandblad voor Accountancy \& Bedrijfseconomie 91(11):405-420

Köhler AG, Quick R, Willekens M (2016) The new European Audit Regulation arena: discussion of new rules and ideas for future research. Int J Audit 20(3):211-214

Knechel WR (2016) Audit quality and regulation. Int J Audit 20(3):215-223

Lee HY, Mande V, Son M (2009) Do lengthy auditor tenure and the provision of non-audit services by the external auditor reduce audit report lags. Int J Audit 13(2):87-104

SDA Università Bocconi, Corporate Finance and Real Estate Department and Administration and Control Department (2002) The impact of mandatory audit rotation on audit quality and on audit pricing: the case of Italy

Publisher's Note Springer Nature remains neutral with regard to jurisdictional claims in published maps and institutional affiliations. 